\title{
Bark Thickness in Coast Redwood (Sequoia sempervirens (D.Don) Endl.) Varies According to Tree- and Crown Size, Stand Structure, Latitude and Genotype
}

\author{
John-Pascal Berrill ${ }^{1, *}$, Kevin L. O'Hara ${ }^{2}\left(\mathbb{C}\right.$ and Nickolas E. Kichas ${ }^{3}$ \\ 1 School of Forest Resources, 201 Nutting Hall, University of Maine, Orono, ME 04469, USA \\ 2 College of Natural Resources, University of California, Berkeley, CA 94720, USA; kohara@berkeley.edu \\ 3 Department of Earth Sciences, 226 Traphagen Hall, Montana State University, Bozeman, MT 59715, USA; \\ nickola.zeibigkichas@montana.edu \\ * Correspondence: pascal.berrill@maine.edu
}

Received: 7 May 2020; Accepted: 1 June 2020; Published: 4 June 2020

\begin{abstract}
Research Highlights: Bark thickness (BT) in coastal redwood (Sequoia sempervirens (D.Don) Endl.) varies in accordance with tree size, crown ratio, position within the canopy, height along the tree stem, genetic identity and latitude. However, current BT predictive equations do not account for such variability, leading to inaccurate BT estimations. We present improved BT models to increase the accuracy of BT estimates for coastal redwood in northern California. Background and Objectives: BT is an important metric that has many practical applications in forest management. However, BT varies substantially across species and environments, as well as across individuals and populations. Our objectives were to investigate BT along various gradients of change, with factors accounting for genetics, tapering of BT along the tree bole, differences in BT according to tree crown position within the stand, and the latitude. Materials and Methods: We collected BT data throughout most of redwood's natural range along a north-south latitudinal gradient. Subsets of these data were used to examine the influence of particular variables on BT while holding the other variables constant. Results: Regionally, the bark was thicker among more xeric southern redwoods and thinner among more mesic northern redwoods. We found that the BT of codominant, intermediate and suppressed trees was around $8 \%, 14 \%$, and $18 \%$ thicker, respectively, than bark of the same size dominant tree. Redwood trees growing in the partial shade of an overstory had thicker bark than trees growing in even-aged stands and incorporating genetic identity yielded major improvements in the BT model estimates, suggesting that BT is under genetic control. Bark thickness decreased with increasing height along the tree stem, with notable differences in the BT above and below breast height. Conclusions: We recommend utilizing the best available BT equations (over standard 'bark factors') in forest science, modeling and management applications. We also recommend the adoption of our drilling method for BT measurement on larger trees due to the potential for error associated with traditional bark gauge measurements.
\end{abstract}

Keywords: bark factor; bark ratio; bark model; tree allometry; uneven-aged silviculture

\section{Introduction}

Understanding how the thickness of tree bark varies within and among trees has practical application in forest science and management. Bark thickness (BT) informs fire science research topics such as modeling post-fire tree mortality because trees with thicker bark are generally more resistant [1]. Dendrochronology researchers studying tree rings can use BT equations to reconstruct historical BT 
for every year the tree was alive [2]. Forest scientists and managers are interested in quantifying tree stem wood volume inside bark from measurements taken outside the bark, without destructive sampling [3-5]. Forest managers contemplating commercial thinning in young stands need estimates of the inside-bark diameter of logs to ensure that cut trees will yield logs meeting merchantability specifications for minimum small-end diameter [6]. In these instances, to derive inside-bark dimensions of wood in trees, we can subtract predictions from BT equations from outside-bark data or model estimates $[7,8]$.

There is also interest in identifying factors influencing BT and how these might be altered by forest management activities. It could be advantageous to enhance BT in fire-prone areas, or reduce BT if this resulted in a concomitant increase in wood production. Tree bark is considered a 'defense feature' that encases living tissues and shields them from external biotic and abiotic forces [9]. A tree's allocation of resources to growth versus defense features such as bark will vary among species $[10,11]$. The strong correlation between tree size and BT signals potential to increase BT by thinning to enhance the tree diameter growth. However, there is some evidence that slower growing trees have a thicker bark relative to their diameter, suggesting that BT is also dependent on tree age [12]. Site quality and soil fertility may influence BT directly, or indirectly by affecting the tree growth rates [13]. Similarly, BT may be controlled indirectly by stand density which influences the tree growth and form and can be altered by forest management [14]. Substantial within-stand variability in tree BT-diameter relationships [9] suggests that additional factors such as genetics are affecting or controlling BT. If BT is under genetic control, there is potential for selection and tree breeding to enhance or reduce BT. If trees from certain regions have thicker or thinner bark gradients [5], we might make selections from these populations in an attempt to produce planting stock with desirable BT. Trees in other parts of California have shown a latitude gradient in BT [9], but this has not been studied in the coast redwood (Sequoia sempervirens (D.Don) Endl.) forests of north coastal California.

Redwood is a shade-tolerant species with morphological plasticity that enables it to respond to disturbances and quickly reoccupy growing space $[15,16]$. Shade tolerance enables suppressed redwood trees to persist in low light, but grow slowly [17]. It is not known whether these suppressed trees have increasing BT with advancing age despite slow diameter growth [18]. Conversely, dominant redwood trees have large crowns intercepting much direct sunlight and exhibit high volume growth efficiency [19], but may have low BT relative to their diameter. Moreover, it is also unknown how redwood BT changes along the length of a tree bole. This information would enable individual logs or standing trees to be more accurately scaled and valued, increasing economic efficiency [20]. While there are published studies correlating BT to tree diameter [21-24], there is comparatively little research which also includes assessments of other candidate factors such as genetics, the tapering of BT along the tree bole, different BT according to tree crown position within the stand and trends in BT according to latitude along the long, narrow north-south range of redwood in northern California.

The objective of our study was to quantify BT along various gradients of change. We hypothesized that redwood BT varied principally according to tree size and height above ground, but also varied according to genetics, crown size, crown position, stand structure and latitude. Specifically, we expected BT to be: (i) less variable within than among distinct genotypes represented by multiple sprouts sharing a root system; (ii) greater at southern latitudes, either due to slower growth on these more xeric sites or as an adaptation to more frequent fire; (iii) greater among older trees in multiaged stands (two or more age classes), where trees underwent some degree of height suppression during their time in the understory, relative to even-aged stands where young trees grow rapidly in full sun with less time to develop thick bark; (iv) greater for older trees of any given size in multiaged stands; and (v) declining exponentially with increasing height above ground.

\section{Materials and Methods}

We collected BT data throughout most of redwood's natural range, from Humboldt County in the north, Mendocino County in the center of redwood's range, down to multiple counties at the 
southern end of the range (Figure 1, Table 1). Subsets of these data were used to examine the influence of particular variables on BT while other influential variables were held constant. We held age constant to test for genetic effects in terms of differences in the BT among sprout clumps in the same stand. Crown class was also held constant to test for regional differences among stands in the north, central, and southern parts of redwood's natural range. We studied stand structure and age effects in data from one region, and the tapering of bark along the stem in a single forest. For the purposes of this study, we use the term tree bark in reference to various tissues including the inner living phloem and dead outer tissue [25]. We use the term BT to refer to the radial linear thickness measurement of all materials outside the xylem, i.e., the combination of cellular structures from inside the cambium layer to the outside of the exterior bark.

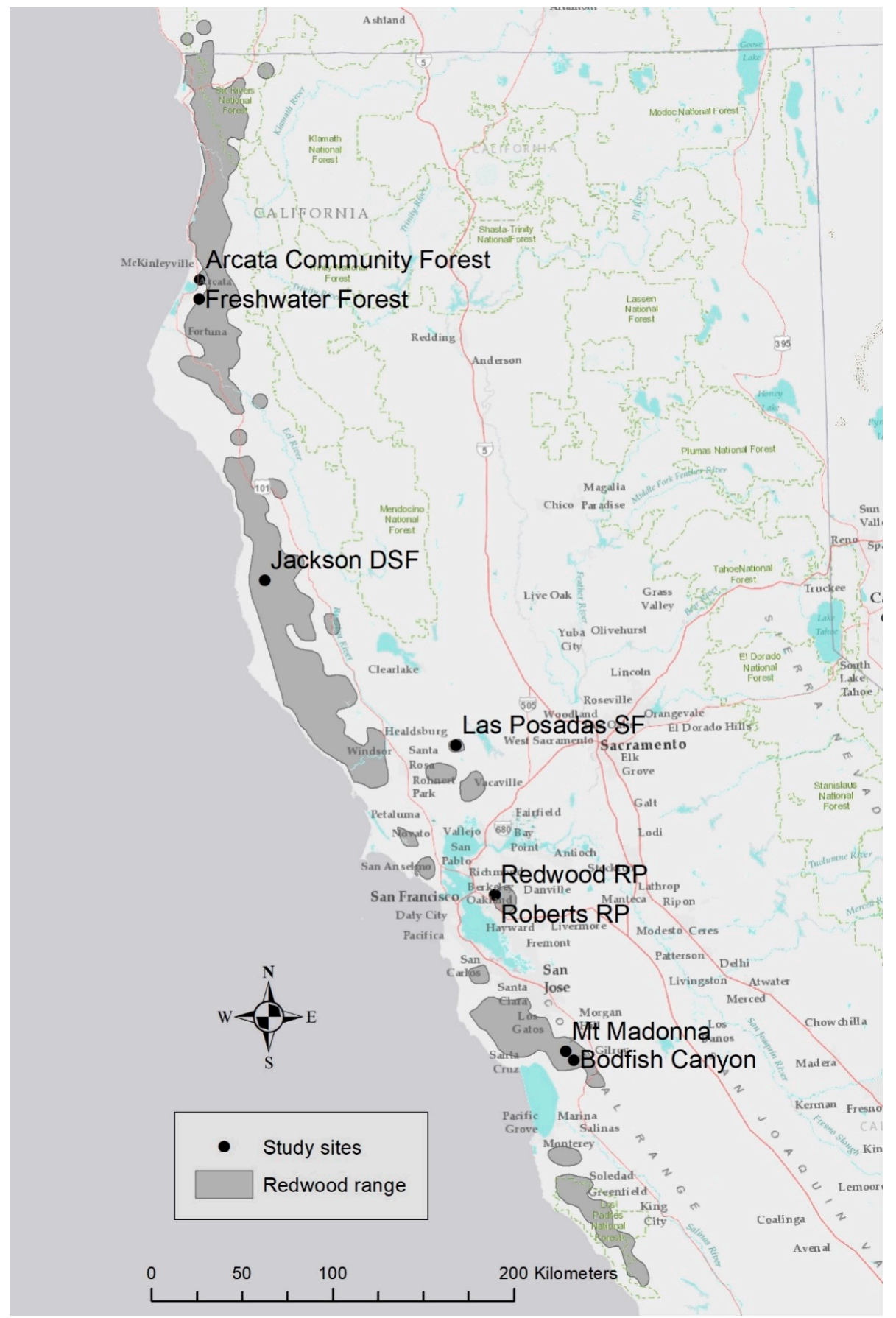

Figure 1. Study sites and approximate range of redwood in northern California and southern Oregon. 
Table 1. Redwood bark thickness study site location information.

\begin{tabular}{ccccc}
\hline Site & County & Latitude & Longitude & Elevation $(\mathbf{m})$ \\
\hline Arcata Community Forest & Humboldt & 40.872169 & -124.070013 & 100 \\
Freshwater Forest & Humboldt & 40.776107 & -124.072185 & 27 \\
Jackson Demonstration State F. & Mendocino & 39.380276 & -123.631004 & 229 \\
Las Posadas State Forest & Napa & 38.559367 & -122.410412 & 404 \\
Roberts Regional Park & Alameda & 37.813329 & -122.175263 & 444 \\
Redwood Regional Park & Alameda & 37.814919 & -122.171610 & 447 \\
Mt. Madonna & Santa Clara & 37.030449 & -121.740942 & 618 \\
Bodfish Canyon & Santa Clara & 36.984844 & -121.692426 & 399 \\
\hline
\end{tabular}

\subsection{Data for Analysis of Clonal Effects}

Jackson Demonstration State Forest (JDSF) is a 20,000 ha redwood-dominated forest managed for research and demonstration objectives using a variety of silvicultural prescriptions. A history of forest management activity has created an assortment of stand structures and age classes available for observational studies. Centrally located in Mendocino County, JDSF has a climate that is intermediate between more mesic northern redwood forests to the north, and more xeric conditions further south and inland. The Mediterranean climate is characterized by warm dry summers, and wet cool winters. Coastal fog regularly extends inland from the Pacific Coast and has a cooling effect throughout the growing season.

In three stands on JDSF, a well stocked area dominated by redwood was selected for measurement. A large rectangular 0.2 ha sample block was established. All trees greater than $10 \mathrm{~cm}$ in diameter at 1.37 $m$ breast height $(\mathrm{DBH})$ were mapped and measured for $\mathrm{DBH}$, total height and height to the live crown base-defined as stem height above which the tree crown was generally continuous on one or more sides. We assigned each tree a crown class: dominant, codominant, intermediate, and suppressed. Pith-to-bark cores collected from dominant trees gave approximate breast height age of the sample stands. BT was measured twice on each tree; for individual stems, uphill and sidehill BT were measured 90 degrees apart, and for redwood stems in clumps-due to the elliptical cross-section with greater growth away from clump center-BT was measured 90 degrees apart on one side, tending towards the center and then again towards the outside of the clump. We used a standard $50 \mathrm{~mm}$ bark gauge on the smaller trees. On the larger trees we used a portable drill and hole saw to remove a cylindrical piece of the bark and expose the cambium. Then, we measured BT between the cambium and the metal tape used to measure the DBH encircling the stem at breast height. This gave the thickness of bark consistent with the method of DBH measurement.

\subsection{Data for Analysis of Regional Differences}

BT data from the southern portion of redwood's range were collected at five sites between Santa Clara County and Napa County [26]. These were relatively hot and dry redwood sites, being located near the inland limits of redwood's range. Two study sites were chosen for sampling in the northern region: Arcata Community Forest and Freshwater Forest, near Humboldt Bay in Humboldt County. The northern sites are shrouded in fog for much of the growing season and have an average mid-summer daytime high temperature of only $18{ }^{\circ} \mathrm{C}$. Summer fog generally dissipates during the daytime at the central sites in Mendocino County and the average summer high temperatures exceed the value of $19^{\circ} \mathrm{C}$ reported for the weather station at the coast. At all the study sites, most rainfall occurs between November and March. The mean annual precipitation is approximately $1000 \mathrm{~mm}$ at the northern and central sites and at the inland Napa County site (Las Posadas State Forest). However, we categorized the Napa site as 'southern' because it receives less fog and its summer temperatures are much higher $\left(30^{\circ} \mathrm{C}\right.$ in July), much like the other southern sites $\left(24-31^{\circ} \mathrm{C}\right)$. Annual precipitation averaged approximately $530 \mathrm{~mm}$ at Gilroy, near the sampling sites at Bodfish Canyon and Mt Madonna 
in Santa Clara County and $660 \mathrm{~mm}$ at Roberts and Redwood Regional Parks in Alameda and Contra Costa Counties, respectively (http://www.weather.com).

Dominant and co-dominant redwood trees approximately 80 to 130 years old and about $110 \mathrm{ft}$ tall were selected for BT measurement in the northern and southern regions: 40 trees from the two northern sites and 25 trees from the five southern sites. BT data for 195 dominant and codominant redwood trees representing the central region were extracted from the following dataset for JDSF.

\subsection{Data for Analysis of Stand Structure and Age Effects}

Throughout the Jackson Demonstration State Forest we established 52 fixed radius plots of various sizes from 0.01 to 0.5 ha: most were 0.02 ha or 0.04 ha. Each plot sampled a forested area absent of recent disturbance or edge effects, but differing in size, structure, and composition. In 23 of these plots, every tree $>5 \mathrm{~cm}$ diameter at breast height (DBH) was measured for $\mathrm{DBH}$, height, and live crown base height. In the remaining plots, every tree $>10 \mathrm{~cm}$ DBH was measured. Trees were assigned a canopy layer (stratum) designation of (A) the crown emergent above main canopy, (B) the crown within the main canopy, and the crown within one or more understory layers $(C, D)$, and assigned one of four crown classes within each stratum. BT was measured once on the smaller trees and measured twice and then averaged for each tree $>20 \mathrm{~cm}$ DBH. A subset of trees (660 out of the 969 measured trees) were cored for breast-height age. Plots with one age class (cohort) of trees were designated as even-aged. Plots with two or more cohorts were designated as multiaged.

\subsection{Data for Analysis of Bark Taper along Stem}

Within the Arcata Community Forest (ACF) in Humboldt County, 31 redwood focal trees were selected at distances $>100 \mathrm{~m}$ apart along a "wandering" transect designed to capture a range of the tree sizes and stand densities. BT and diameter measurements were taken at intervals from the base of the stem to the base of the live canopy. Trees were climbed using the flip-line and spur method and the diameter was repeatedly measured along the stem. At the same height of each diameter measurement, the BT was measured twice 90 degrees apart using a standard $50 \mathrm{~mm}$ bark gauge. The BT was measured from the wood surface to the contour of the diameter tape wrapped around the tree [27]. Measurements were separated vertically by roughly $0.30 \mathrm{~m}$ at heights below $2 \mathrm{~m}$ and roughly $3 \mathrm{~m}$ above $2 \mathrm{~m}$ in height with the final measurement taken upon reaching the live crown base. More frequent diameter and BT measurements were taken below $2 \mathrm{~m}$ to account for the greater tapering of BT near the tree base.

To evaluate the influence of stand density on BT, each focal tree that we climbed was designated as the center of a variable-radius plot. DBH was measured for each plot tree, and used to calculate stand density index (SDI) [28] using the angle-summation method [29]. The basal area factor (BAF) was selected based on a desire to have five to nine trees within the plot. Plots with relatively low density were established using a $4.59 \mathrm{~m}^{2} \mathrm{ha}^{-1}$ BAF prism, moderate density plots with a $9.18 \mathrm{~m}^{2} \mathrm{ha}^{-1}$ BAF prism, and high density plots were established with a $13.77 \mathrm{~m}^{2} \mathrm{ha}^{-1}$ BAF prism.

\subsection{Analysis}

We analyzed the nested data for genetic effect on the BT using the generalized linear mixed-effects regression with PROC GLIMMIX in SAS [27]. The fixed effects were tree DBH, crown ratio (CR), and the categorical variable: crown class. We incorporated a random effect for the class variable: CloneID, a unique identifier for each clump of redwood sprout-origin stems. For the analysis of north-south latitudinal gradient in BT, we used generalized linear regression (PROC GLM) analysis with categorical variables for the region (north, central, south) and the continuous variables DBH and CR. Similarly, for the analysis of the stand structure effects, we used GLM with a categorical binary variable for even-aged or multiaged stand structure, and continuous variables for DBH and CR. The analysis of tree age and canopy position was also done using GLM with the categorical variable canopy strata (emergent, main canopy, understory) and continuous variables: DBH, CR, and breast-height age. For 
each of these analyses, the response variable was transformed to reduce skewness in the distribution of the BT data. We used Akaike's Information Criterion AIC for model selection, where decreases greater than 2 points were considered significant improvements [30].

Lastly, we developed a BT taper equation predicting the BT for any height along the tree bole. For analysis, the measurement height data were converted to a proportion of the total tree height $(\mathrm{HT})$ above breast height $(\mathrm{BH})$, such that:

$$
\text { Measurement HT relative to } \mathrm{BH}=\frac{\text { Measurement } \mathrm{HT}-1.37}{\text { Tree } \mathrm{HT}-1.37}
$$

BT was also converted to a proportion of breast height BT. Our BT data exhibited negative exponential tapering with increasing height above ground, so we subtracted our measurement height relative to the breast height from one to invert the data in order to fit a nonlinear power model. After preliminary analysis it was decided that two separate nonlinear equations (one for above $\mathrm{BH}$ and one for below $\mathrm{BH}$ ) would better represent redwood BT tapering which appeared to taper more rapidly below breast height; Maguire and Hann [8] also used separate equations to model the tapering of BT above and below breast height. We excluded the data for one outlier tree with unusual bark taper characteristics. Data were analyzed using PROC NLIN in SAS [31].

\section{Results}

\subsection{Bark Thickness in Even-Aged Stands-Effects of Tree Size, Taper, Crown Ratio, and Genetics}

Holding the stand age constant at 85 years in two stands and 100 years in the third even-aged stand allowed us to isolate the effects of tree variables and quantify variation in the breast-height BT among the genotypes (i.e., $n=74$ individual sprout clumps comprising $2-12$ trees). Each sample stand had a different mean and maximum tree size, but a similar basal area comprised of more or less trees (Table 2). Size-differentiation was pronounced, with many trees in the suppressed crown class (Table 3).

Table 2. Summary data for 0.2 ha plot in three even-aged stands at age 85-100 years in the Jackson Demonstration State Forest.

\begin{tabular}{cccc}
\hline & Stand 1 & Stand 2 & Stand 3 \\
\hline Position on slope & Ridge & Gully & Upslope \\
Age & 85 & 100 & 85 \\
Area (ha) & 0.2 & 0.2 & 0.2 \\
Number of trees sampled & 263 & 78 & 230 \\
Density (stems/ha) & 1315 & 390 & 1150 \\
Average DBH (mm) & 332 & 610 & 398 \\
Maximum DBH (mm) & 926 & 1394 & 1127 \\
Maximum height (m) & 44.6 & 63.8 & 50.1 \\
Basal area (m $\left.\mathrm{ha}^{-1}\right)$ & 144.7 & 142.0 & 179.0 \\
Stemwood volume $\left(\mathrm{m}^{3} \mathrm{ha}^{-1}\right)$ & 1286 & 2126 & 1961 \\
\hline
\end{tabular}

Several models of the BT in even-aged stands had equivalent AIC. The most parsimonious model included DBH and crown class. Testing CloneID as a fixed effect gave a major improvement in AIC, indicating that the BT differed among the sprout clumps and was under genetic control (Table 4). In this model, solutions for fixed effects indicated that the BT varied within a $6.4 \mathrm{~mm}$ range $(-1.0-5.4 \mathrm{~mm})$ among sprout clumps. 
When CloneID was treated as a random effect, an important amount of variation in BT was detected among sprout clumps (Table 5). There was relatively more random (residual) variation in the BT than among the genotypes, and more variation among sprout-clump genotypes (CloneID) than among the three sample stands (Plot) (Table 5). The best BT model indicated that the bark was thickest among the suppressed trees and thinnest among the dominant trees, after controlling for the tree size and age effects in the GLM analysis. Comparing the modeled BT among redwood trees with 450-650 mm DBH (i.e., where the data for all the crown classes were available), the bark of codominant, intermediate, and suppressed trees was around $8 \%, 14 \%$, and $18 \%$ thicker, respectively, than the bark of the same size dominant tree (Figure 2).

Table 3. Summary data for redwood trees in each crown class in three even-aged stands at age 85-100 years in Jackson Demonstration State Forest.

\begin{tabular}{ccccccc}
\hline Variable & Crown Class & $\boldsymbol{n}$ & Mean & s.d. & Min. & Max. \\
\hline \multirow{5}{*}{ Bark thickness $(\mathrm{mm})$} & All trees & 571 & 35.59 & 22.06 & 1.00 & 119.50 \\
& Dominant & 67 & 60.05 & 18.87 & 34.50 & 111.50 \\
& Codominant & 100 & 54.34 & 17.90 & 24.50 & 119.50 \\
& Intermediate & 78 & 46.40 & 12.32 & 24.50 & 75.50 \\
& Suppressed & 326 & 22.23 & 14.47 & 1.00 & 72.00 \\
\hline & All trees & 571 & 396.69 & 224.55 & 100.00 & 1394.00 \\
& Dominant & 67 & 700.90 & 196.33 & 453.00 & 1394.00 \\
DBH $(\mathrm{mm})$ & Codominant & 100 & 609.56 & 185.89 & 305.00 & 1165.00 \\
& Intermediate & 78 & 461.92 & 99.55 & 310.00 & 784.00 \\
& Suppressed & 326 & 253.26 & 114.26 & 100.00 & 660.00 \\
\hline \multirow{5}{*}{ Crown ratio } & All trees & 571 & 0.31 & 0.10 & 0.01 & 0.69 \\
& Dominant & 67 & 0.38 & 0.08 & 0.19 & 0.60 \\
& Codominant & 100 & 0.37 & 0.08 & 0.20 & 0.64 \\
& Intermediate & 78 & 0.31 & 0.08 & 0.15 & 0.53 \\
& Suppressed & 326 & 0.28 & 0.10 & 0.01 & 0.69 \\
\hline \multirow{5}{*}{ Height:diameter ratio } & All trees & 571 & 0.83 & 0.19 & 0.32 & 1.45 \\
& Dominant & 67 & 0.66 & 0.11 & 0.35 & 0.87 \\
& Codominant & 100 & 0.70 & 0.11 & 0.49 & 1.05 \\
& Intermediate & 78 & 0.79 & 0.11 & 0.44 & 1.05 \\
& Suppressed & 326 & 0.91 & 0.19 & 0.32 & 1.45 \\
\hline
\end{tabular}

Table 4. Comparing candidate even-aged redwood bark thickness (BT) models. Generalized linear mixed-effects models for square-root transformed BT $(\mathrm{mm})$ as a function of candidate fixed effects: $\mathrm{DBH}$, height:diameter ratio (HD), crown ratio (CR), crown class (CC), and a unique sprout clump identifier (CloneID) included in every model as either a fixed or a random effect. Models fitted to redwood tree data $(n=571)$ for three even-aged stands at age 85 years in Jackson Demonstration State Forest.

\begin{tabular}{|c|c|c|}
\hline Candidate Models & AIC & $\Delta \mathrm{AIC}$ \\
\hline $\mathrm{BT}^{0.5}=\beta_{0}+\beta_{1} \operatorname{LnDBH}+\beta_{2}$ CClass $+\beta_{3}$ CloneID & 980.04 & - \\
\hline $\mathrm{BT}^{0.5}=\beta_{0}+\beta_{1} \operatorname{Ln} \mathrm{DBH}+\beta_{2} \mathrm{CR}+\beta_{3} \operatorname{Ln} \mathrm{DBH} \times \mathrm{CR}+\beta_{4} \mathrm{CC}$ & 1121.42 & 141.38 \\
\hline $\mathrm{BT}^{0.5}=\beta_{0}+\beta_{1} \operatorname{Ln} \mathrm{DBH}+\beta_{2} \mathrm{CClass}$ & 1121.69 & 141.65 \\
\hline $\mathrm{BT}^{0.5}=\beta_{0}+\beta_{1} \operatorname{Ln} \mathrm{DBH}+\beta_{2} \mathrm{CR}+\beta_{3}$ CClass & 1121.73 & 141.69 \\
\hline $\mathrm{BT}^{0.5}=\beta_{0}+\beta_{1} \operatorname{Ln} \mathrm{DBH}+\beta_{2} \mathrm{HD}+\beta_{3}$ CClass & 1121.97 & 141.93 \\
\hline $\mathrm{BT}^{0.5}=\beta_{0}+\beta_{1} \operatorname{Ln} \mathrm{DBH}+\beta_{2} \mathrm{HD}+\beta_{3} \operatorname{Ln} \mathrm{DBH} \times \mathrm{HD}+\beta_{4} \mathrm{CC}$ & 1123.00 & 142.96 \\
\hline $\mathrm{BT}^{0.5}=\beta_{0}+\beta_{1} \operatorname{Ln} \mathrm{DBH}+\beta_{2} \mathrm{CR}+\beta_{3} \operatorname{Ln} \mathrm{DBH} \times \mathrm{CR}$ & 1146.24 & 166.20 \\
\hline $\mathrm{BT}^{0.5}=\beta_{0}+\beta_{1} \operatorname{LnDBH}+\beta_{2} \mathrm{HD}+\beta_{3} \operatorname{Ln} \mathrm{DBH} \times \mathrm{HD}$ & 1146.44 & 166.40 \\
\hline $\mathrm{BT}^{0.5}=\beta_{0}+\beta_{1} \operatorname{LnDBH}$ & 1149.83 & 169.79 \\
\hline
\end{tabular}


Table 5. Even-aged redwood bark thickness (BT) model. Linear mixed-effects model for square-root transformed BT $(\mathrm{mm})$ in each crown class as a function of DBH $(\mathrm{mm})$ at age 85 years in three even-aged stands in Jackson Demonstration State Forest.

\begin{tabular}{ccccccc}
\hline Effect & Variable & Estimate & s.e. & DF & $\boldsymbol{t}$ Value & Pr $>|\mathbf{t}|$ \\
\hline \multirow{5}{*}{ Fixed } & Intercept & -15.6668 & 0.5105 & 2 & -30.69 & 0.0011 \\
& LnDBH & 3.6526 & 0.0806 & 490 & 45.30 & $<0.0001$ \\
& Dominant & -0.6847 & 0.1170 & 490 & -5.85 & $<0.0001$ \\
& Codominant & -0.3876 & 0.1007 & 490 & -3.85 & 0.0001 \\
& Intermediate & -0.1497 & 0.0938 & 490 & -1.60 & 0.1110 \\
& Suppressed & 0 & - & - & - & - \\
\hline \multirow{5}{*}{ Random } & Plot & 0.1471 & 0.1520 & & & \\
& CloneID & 0.2327 & 0.0589 & & & \\
& Residual & 0.3442 & 0.0219 & & & \\
\hline
\end{tabular}

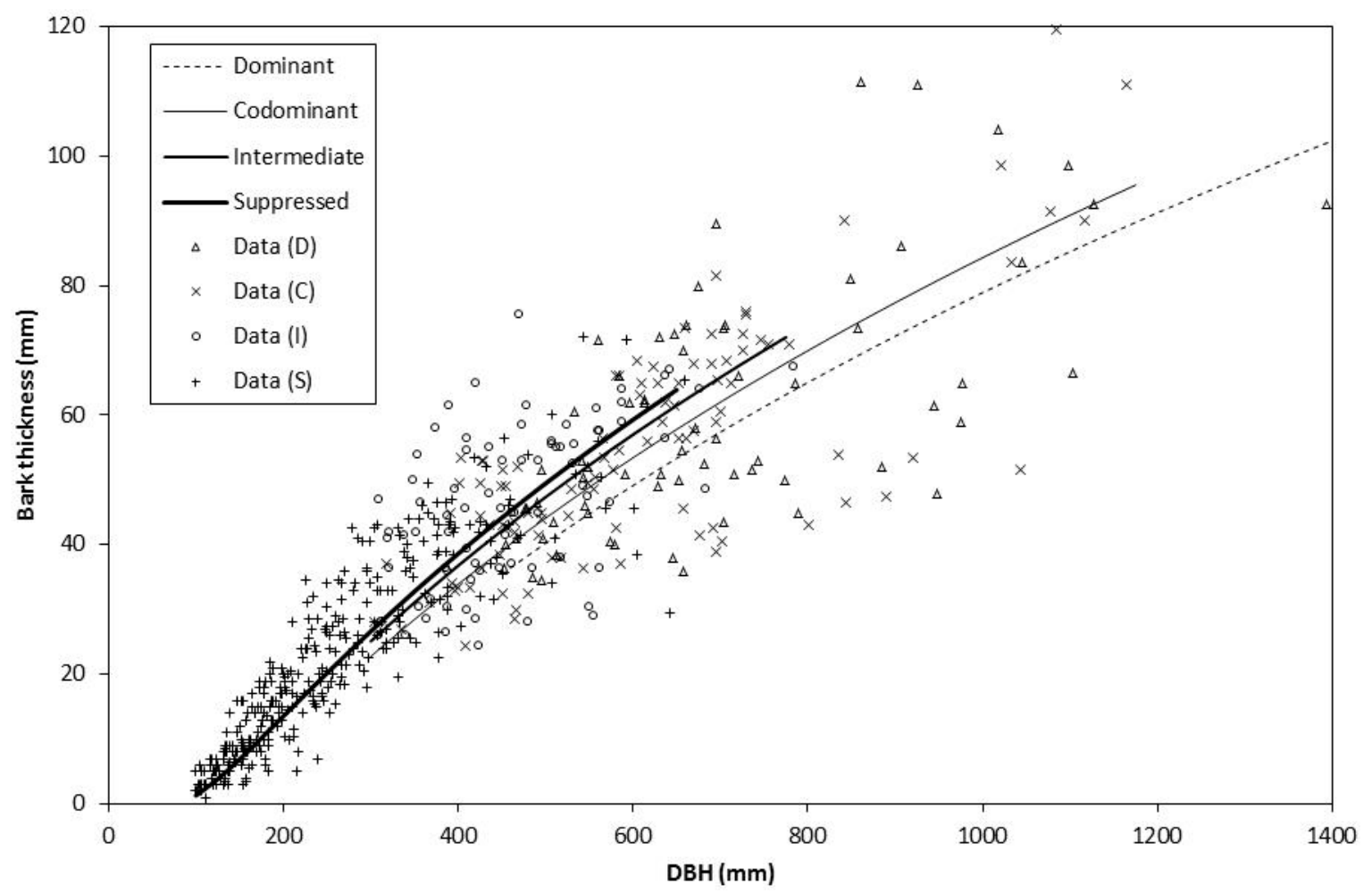

Figure 2. Redwood bark thickness data and linear mixed-effects model predictions for each crown class at age 85 years in three even-aged stands in Jackson Demonstration State Forest.

\subsection{Bark Thickness of Dominants and Codominants along North-South Gradient}

In light of the differences among the crown classes, we analyzed a subset of data for only the dominant and codominant redwood trees of similar size and age in the northern, central, and southern portions of redwood's natural range. We excluded the data for trees below $470 \mathrm{~mm} \mathrm{DBH}$, the size of the smallest tree measured in the southern region which had the fewest data (Table 6). The improvement of 24 AIC points indicated that the BT differed among the regions. The bark was significantly thicker at breast height among the southern redwoods and thinner among northern redwoods (Table 7).

\subsection{Bark Thickness in Even-Aged and Multiaged Stands-Effects of Stand Structure}

Redwood trees sampled for BT in even-aged stands had shorter crowns than trees of comparable size in multiaged stands (Table 8 ). Distinguishing between the even-aged and multiaged stands using a dummy variable and incorporating the crown ratio into BT models gave a significant improvement 
in the model fit (Table 9). The best model indicated that redwood trees growing in the partial shade of an overstory had thicker bark than trees growing in even-aged stands, after accounting for the effects of tree size (positive) and crown ratio (negative) on BT (Table 10).

Table 6. Summary data for redwood trees in the northern, central, and southern parts of redwood's natural range.

\begin{tabular}{ccccccc}
\hline Variable & Region & $\boldsymbol{n}$ & Mean & s.d. & Min. & Max. \\
\hline \multirow{3}{*}{ DBH $(\mathrm{mm})$} & North & 40 & 791.65 & 211.43 & 487.70 & 1342.00 \\
& Central & 195 & 684.03 & 187.81 & 471.00 & 1562.10 \\
& South & 25 & 745.24 & 167.58 & 471.00 & 1103.00 \\
\hline \multirow{3}{*}{ Crown ratio } & North & 40 & 0.66 & 0.11 & 0.46 & 0.91 \\
& Central & 195 & 0.52 & 0.16 & 0.15 & 1.00 \\
& South & 25 & 0.58 & 0.14 & 0.36 & 0.89 \\
\hline \multirow{3}{*}{ Bark thickness (mm) } & North & 40 & 57.36 & 20.13 & 31.80 & 117.50 \\
& Central & 195 & 57.39 & 17.31 & 22.00 & 117.00 \\
& South & 25 & 80.58 & 28.79 & 31.50 & 164.00 \\
\hline
\end{tabular}

Table 7. Bark thickness (BT) model for dominant and codominant redwoods in the northern, central, and southern parts of redwood's natural range (regional model) and for all the data combined (range-wide model). Generalized linear model for the natural $\log (L n)$-transformed BT $(\mathrm{mm})$ as a function of $\mathrm{DBH}(\mathrm{mm})$.

\begin{tabular}{cccccccc}
\hline Model & Variable & Estimate & s.e. & DF & $\boldsymbol{t}$ Value & Pr $>|\mathbf{t}|$ & AIC \\
\hline \multirow{5}{*}{ Regional } & Intercept & -0.1846 & 0.418 & 0 & -0.44 & $<0.0001$ & 31.71 \\
& LnDBH & 0.6855 & 0.063 & 256 & 10.88 & $<0.0001$ & \\
& North & -0.3704 & 0.064 & 256 & -5.83 & $<0.0001$ & \\
& Central & -0.2608 & 0.053 & 256 & -4.90 & $<0.0001$ & \\
& South & 0 & - & - & - & - & \\
\hline \multirow{2}{*}{ Range wide } & Intercept & -0.4013 & 0.4261 & 0 & -0.94 & $<0.0001$ & 56.19 \\
& LnDBH & 0.6800 & 0.06524 & 258 & 10.42 & $<0.0001$ & \\
\hline
\end{tabular}

Table 8. Summary data for the redwood trees in even-aged stands versus understory trees in multiaged stands. Data for trees $<400 \mathrm{~mm} \mathrm{DBH}(n=279)$ collected in 32 plots sampling even-aged and multiaged stands in Jackson Demonstration State Forest.

\begin{tabular}{ccccccc}
\hline Variable & Stand Structure & $\boldsymbol{n}$ & Mean & s.d. & Min. & Max. \\
\hline \multirow{2}{*}{ DBH $(\mathrm{mm})$} & Even-aged & 41 & 170.43 & 79.59 & 73.66 & 398.78 \\
& Multiaged & 238 & 153.86 & 74.82 & 50.00 & 370.00 \\
\hline \multirow{2}{*}{ Crown ratio } & Even-aged & 41 & 0.54 & 0.17 & 0.19 & 0.85 \\
& Multiaged & 238 & 0.72 & 0.18 & 0.25 & 0.99 \\
\hline \multirow{2}{*}{ Bark thickness $(\mathrm{mm})$} & Even-aged & 41 & 11.76 & 9.04 & 2.00 & 36.50 \\
& Multiaged & 238 & 12.28 & 9.67 & 1.00 & 58.00 \\
\hline
\end{tabular}

Table 9. Comparing candidate redwood bark thickness (BT) models. Generalized linear models for natural $\log (\mathrm{Ln})$-transformed BT $(\mathrm{mm})$ as a function of the candidate predictor variables: $\mathrm{DBH}$, crown ratio $(\mathrm{CR})$, and a dummy variable for redwood trees in even-aged stands versus understory trees in multiaged stands in Jackson Demonstration State Forest.

\begin{tabular}{lcc}
\hline \multicolumn{1}{c}{ Candidate Models } & AIC & $\Delta$ AIC \\
\hline $\operatorname{Ln} \mathrm{BT}=\beta_{0}+\beta_{1} \operatorname{Ln} \mathrm{DBH}+\beta_{2} \mathrm{CR}+\beta_{3}$ Even-aged & 376.13 & - \\
$\operatorname{Ln} \mathrm{BT}=\beta_{0}+\beta_{1} \operatorname{Ln} \mathrm{DBH}+\beta_{2}$ Even-aged & 381.52 & 5.39 \\
$\operatorname{Ln} \mathrm{BT}=\beta_{0}+\beta_{1} \operatorname{Ln} \mathrm{DBH}+\beta_{2} \mathrm{CR}$ & 383.15 & 7.02 \\
$\operatorname{Ln} \mathrm{BT}=\beta_{0}+\beta_{1} \operatorname{Ln} \mathrm{DBH}$ & 384.16 & 8.03 \\
\hline
\end{tabular}


Table 10. Bark thickness (BT) model for redwood trees in even-aged stands and understory trees in multiaged stands. Generalized linear model for natural $\log (L n)$-transformed BT $(\mathrm{mm})$ as a function of $\mathrm{DBH}(\mathrm{mm})$ and crown ratio.

\begin{tabular}{cccccc}
\hline Variable & Estimate & s.e. & DF & $\boldsymbol{t}$ Value & $\operatorname{Pr}>|\mathbf{t}|$ \\
\hline Intercept & -4.9977 & 0.2988 & 0 & -16.73 & $<0.0001$ \\
LnDBH & 1.5192 & 0.0583 & 275 & 26.08 & $<0.0001$ \\
Crown ratio & -0.4170 & 0.1536 & 275 & -2.72 & 0.0070 \\
Even-aged & -0.2669 & 0.0831 & 275 & -3.21 & 0.0015 \\
Multiaged & 0 & - & - & - & - \\
\hline
\end{tabular}

\subsection{Effect of Tree Age and Canopy Layer on Bark Thickness in Multiaged Stands}

To avoid the confounding effect of stand structure, we extracted a subset of data for sample trees of known age that were exclusively located in multiaged stands. These trees covered a broad range of ages, sizes and crown ratios (Table 11). Accounting for the position of each tree crown within the stand by assigning it to a canopy layer (i.e., canopy stratum) did not improve the BT models (Table 12). Breast-height age was a more useful predictor of the BT than the canopy stratum. Older trees of a given size and crown ratio were found to have thicker bark, however the age effect was not pronounced and a simpler model without age had the same AIC (Table 13). The best model included DBH and CR and represented a significant improvement over the simplest model predicting BT as a function of DBH alone.

Table 11. Summary data for redwood trees separated into three canopy layers (strata) in even-aged and multiaged stands. Data for trees with breast-height age data $(n=565)$ collected in 48 plots sampling even-aged and multiaged stands in Jackson Demonstration State Forest.

\begin{tabular}{ccccccc}
\hline Variable & Canopy Stratum & $\boldsymbol{n}$ & Mean & s.d. & Min. & Max. \\
\hline \multirow{3}{*}{ DBH $(\mathrm{mm})$} & Emergent & 38 & 973.92 & 240.78 & 625.00 & 1562.10 \\
& Main canopy & 336 & 442.80 & 206.70 & 58.42 & 1130.30 \\
& Understory & 191 & 154.85 & 72.75 & 51.00 & 357.00 \\
\hline \multirow{3}{*}{ Crown ratio } & Emergent & 38 & 0.54 & 0.11 & 0.37 & 0.80 \\
& Main canopy & 336 & 0.51 & 0.18 & 0.14 & 1.00 \\
& Understory & 191 & 0.70 & 0.19 & 0.21 & 0.99 \\
\hline \multirow{3}{*}{ Tree age (years) } & Emergent & 38 & 98.08 & 12.45 & 60.00 & 131.00 \\
& Main canopy & 336 & 61.51 & 23.98 & 13.00 & 130.00 \\
& Understory & 191 & 28.83 & 17.42 & 6.00 & 100.00 \\
\hline \multirow{3}{*}{ Bark thickness (mm) } & Emergent & 38 & 67.89 & 15.85 & 36.00 & 117.00 \\
& Main canopy & 336 & 40.22 & 19.19 & 3.00 & 109.00 \\
& Understory & 191 & 12.36 & 9.90 & 1.00 & 58.00 \\
\hline
\end{tabular}

Table 12. Comparing candidate multiaged redwood bark thickness (BT) models. Generalized linear models for square root-transformed BT $(\mathrm{mm})$ as a function of the candidate predictor variables: $\mathrm{DBH}$, crown ratio (CR), breast-height age (years) and the categorical variables for redwood trees in the different canopy strata and in even-aged stands versus multiaged stands in Jackson Demonstration State Forest.

\begin{tabular}{lcc}
\hline \multicolumn{1}{c}{ Candidate Models } & AIC & $\Delta$ AIC \\
\hline $\mathrm{BT}^{0.5}=\beta_{0}+\beta_{1} \operatorname{LnDBH}+\beta_{2} \mathrm{CR}+\beta_{3} \mathrm{Age}^{0.5}$ & 1337.60 & - \\
$\mathrm{BT}^{0.5}=\beta_{0}+\beta_{1} \operatorname{Ln} \mathrm{DBH}+\beta_{2} \mathrm{CR}$ & 1337.90 & 0.30 \\
$\mathrm{BT}^{0.5}=\beta_{0}+\beta_{1} \operatorname{Ln} \mathrm{DBH}+\beta_{2} \mathrm{CR}+\beta_{3} \mathrm{Age}^{0.5}+\beta_{4}$ Stratum & 1338.85 & 1.25 \\
$\mathrm{BT}^{0.5}=\beta_{0}+\beta_{1} \operatorname{Ln} \mathrm{DBH}+\beta_{2} \mathrm{CR}+\beta_{3}$ Stratum & 1340.26 & 2.66 \\
$\mathrm{BT}^{0.5}=\beta_{0}+\beta_{1} \operatorname{Ln} \mathrm{DBH}$ & 1361.80 & 24.20 \\
\hline
\end{tabular}


Table 13. Bark thickness (BT) models for redwood trees in multiaged stands. Generalized linear model for the square root-transformed BT $(\mathrm{mm})$ as a function of DBH $(\mathrm{mm})$ and crown ratio, with and without breast-height age (years).

\begin{tabular}{cccccccc}
\hline Model & Variable & Estimate & s.e. & DF & $t$ Value & Pr $>|t|$ & AIC \\
\hline \multirow{5}{*}{ Age effect } & Intercept & -8.6640 & 0.3059 & 0 & -28.32 & $<0.0001$ & 1337.60 \\
& LnDBH & 2.4423 & 0.0713 & 561 & 34.26 & $<0.0001$ & \\
& CR & -0.6628 & 0.1919 & 561 & -3.45 & 0.0006 & \\
& Age ${ }^{0.5}$ & 0.0675 & 0.0285 & 561 & 2.36 & 0.0184 & \\
\hline \multirow{3}{*}{ Without age } & Intercept & -8.8130 & 0.3005 & 0 & -29.32 & $<0.0001$ & 1337.90 \\
& LnDBH & 2.5726 & 0.0454 & 562 & 56.68 & $<0.0001$ & \\
& $\mathrm{CR}$ & -0.8729 & 0.1707 & 562 & -5.11 & $<0.0001$ & \\
\hline
\end{tabular}

\subsection{Bark Tapering along the Stem}

Dominant and codominant trees sampled for bark tapering covered a range of tree sizes (Table 14). The resultant dataset for the modeling of BT tapering comprised a total of 129 measurements of BT at different heights below breast height and 208 measurements above breast height.

Table 14. Summary data for DBH and the breast-height bark thickness (BT) of redwood trees sampled for bark tapering (BT at various heights) at Arcata Community Forest, Humboldt County, California.

\begin{tabular}{cccccc}
\hline Variable & $\boldsymbol{n}$ & Mean & s.d. & Min. & Max. \\
\hline DBH $(\mathrm{mm})$ & 31 & 703.79 & 288.27 & 182.90 & 1342.00 \\
Bark thickness $(\mathrm{mm})$ & 31 & 48.86 & 24.15 & 10.20 & 110.50 \\
\hline
\end{tabular}

Our sample of 31 trees from the ACF revealed relatively consistent decreases in BT with increasing height along the tree stem. However, there were notable differences in the BT above and below the breast height, which led to the formulation of two separate models to predict BT tapering for each respective segment (above and below breast height).

Lower variability in BT above breast height led to more precise predictions of BT ( $6.76 \mathrm{~mm}$ root mean square error (RMSE)) when the non-linear model of BT as a proportion of the breast-height BT $\left(\mathrm{BT}_{\mathrm{BH}}\right)$ was rearranged to predict the actual $\mathrm{BT}(\mathrm{mm})$ for each sample measurement height $\left(\mathrm{H}_{\mathrm{BT}}\right)$ above the breast height, such that:

$$
\text { Proportion of } \mathrm{BT}_{\mathrm{BH}}=\left(1-\mathrm{H}_{\mathrm{BT}} /(\mathrm{HT}-1.37)\right)^{1.977}
$$

Greater variability in the BT below breast height led to less precise nonlinear power model predictions (7.49 $\mathrm{mm}$ RMSE) for the BT ( $\mathrm{mm}$ ) below breast height where:

$$
\text { Proportion of } \mathrm{BT}_{\mathrm{BH}}=\left(10.686 *\left(\left(1-\mathrm{H}_{\mathrm{BT}} /(\mathrm{HT}-1.37)\right)-1\right)^{1.151}\right)+1
$$

Bark thickness (BT) tapering above and below breast height (BH) varies according to the total tree height. The rate of tapering below breast height ranks from least to most rapid for three redwood trees of different heights: $50 \mathrm{~m}, 35 \mathrm{~m}$, and $20 \mathrm{~m}$ total height (Figure 3). Model predictions of BT tapering show how BT quickly becomes thinner above breast height, and thickens below breast height. For example, halfway up a $50 \mathrm{~m}$ tree, the nonlinear model predicts that the BT is only $26.8 \%$ of breast-height BT. Similarly, halfway up a $35 \mathrm{~m}$ tree, BT is $27.5 \%$ of the breast height BT, and halfway up a $20 \mathrm{~m}$ tree, BT is $29.2 \%$ of the breast height BT. Within the tree crown, towards the tree top, BT tapers less (Figure 3). 


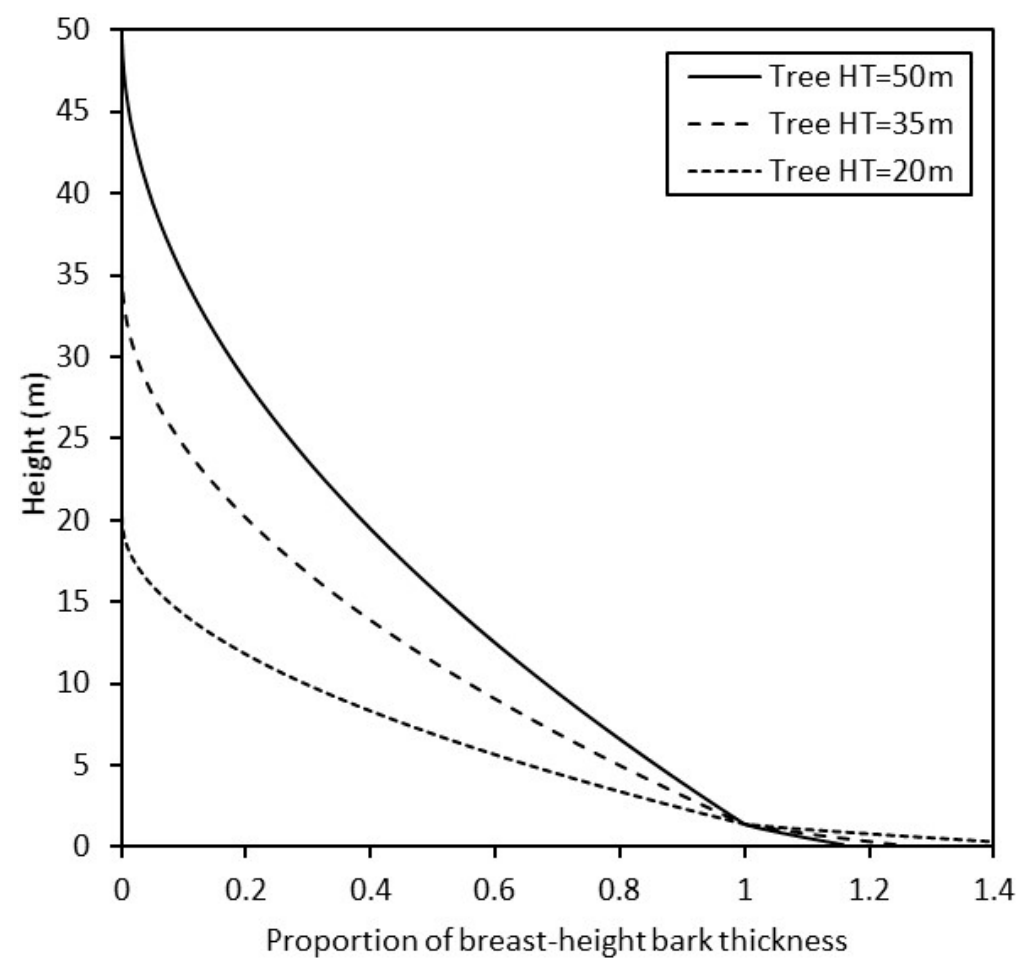

Figure 3. Modeled bark thickness (BT) tapering above and below the breast height $(1.37 \mathrm{~m})$ for three redwood trees of different heights: $50 \mathrm{~m}, 35 \mathrm{~m}$, and $20 \mathrm{~m}$ total height.

\section{Discussion}

Redwood BT was most strongly associated with DBH, but was also found to be negatively correlated with the $\mathrm{CR}$. Like CR, crown class was negatively correlated with $\mathrm{BT}$, meaning that among trees of a given DBH, dominant trees had the least BT and suppressed trees had the most BT. After including these influential tree variables in the BT regressions, other factors explaining additional variation in BT included genotype, stand structure (BT ranked even-aged $<$ multiaged), and geographic region (BT ranked north $<$ central < southern regions). The regional variation in BT has also been detected among Sierra Nevada conifers throughout California [12] but not white spruce (Picea glauca) across Alaska [32].

The influence of stand structure on the BT manifested itself as greater BT for redwoods grown in multiaged versus even-aged stands. This difference was detected even after accounting for the influence of DBH and CR. We expected trees in multiaged stands to be older than trees of the same size in even-aged stands, and have different stem and crown allometry and branching characteristics [11,33-35]. For example, crowns of the shade-tolerant Pacific silver fir (Abies amabilis) had longer crowns when grown in shade, and presumably different branching patterns and allometry [35]. Stem allometry and tapering of bark along the stem may also vary between redwoods grown in multiaged versus even-aged stands, requiring more investigation. Marshall et al. [4] found that the Douglas-fir BT varied among stands, and recommended applying localized coefficients to account for this source of variation in BT. In addition, it is unknown how the patterns of BT tapering along the stem may also vary regionally. Pemberton [36] reported on the tapering of BT in terms of bark factor at BH (av. 15.6\%, range $14-16 \%$ ) and the half height (av. $10.7 \%$ of stem diameter at half height, range $9.7-11.1 \%$ ) for redwood in Del Norte and Humboldt Counties.

Other factors may also influence the BT in redwood and other species. The thick bark on redwood that imparts resistance to fire is often partially consumed in non-lethal ground fires (Figure 4). Hence, the BT near the ground on large trees may be less than further up the stem. Similarly, anthropogenic burning may have favored trees with thicker BT as reported in Pinus radiata [37]. Bark thickness in redwood has also been reported to shrink and swell with variations in moisture content [38]. 


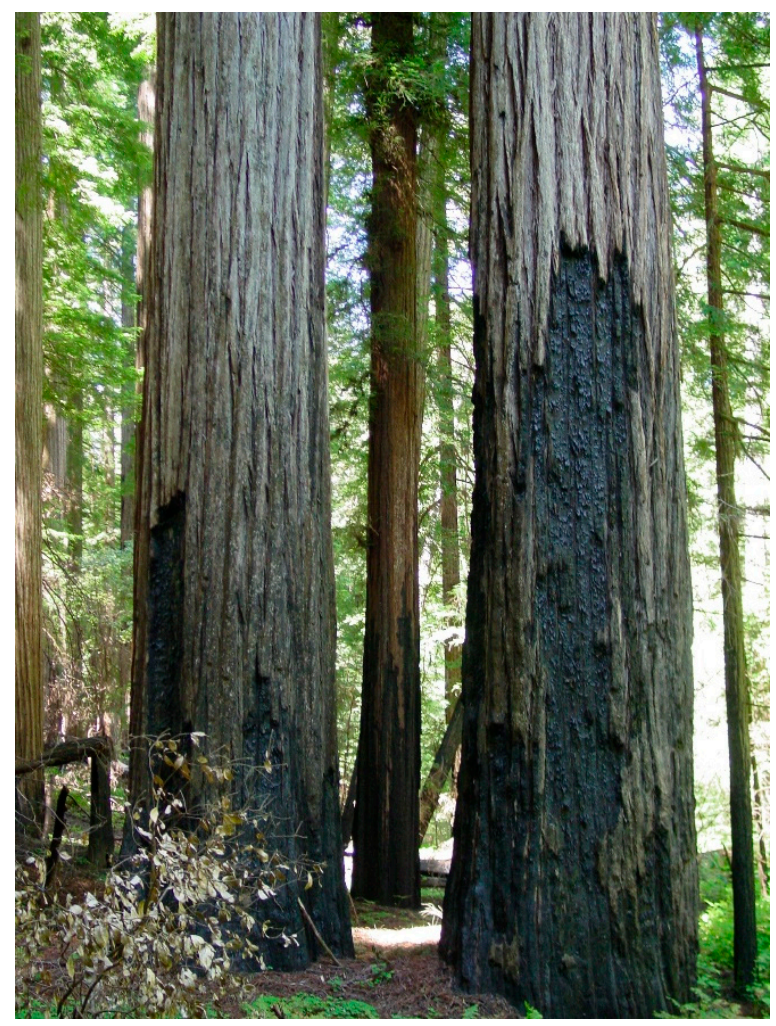

Figure 4. Bark of old redwood trees partially consumed by wildfire.

In multiaged stands, older trees of a given size and crown ratio were found to have slightly thicker bark, but the age effect was not pronounced. A simpler BT model without age included DBH and CR, and itself represented a major improvement in predictive power over the simplest model predicting the BT in multiaged stands as a function of DBH alone. This finding has practical significance. First, it appears that a generalized BT model applies to all trees in multiaged stands which means it will make consistent predictions when implemented within individual tree growth and yield modeling frameworks predicting change in the DBH and CR over time. Secondly, the importance of CR and DBH for the prediction of BT suggests that constant 'bark factors' (sometimes referred to as bark ratios) $[36,39]$ will be inadequate for many applications. In particular, trees at either extreme of DBH or CR will have the BT under/overpredicted by a constant bark factor. For example, Pemberton [36] reported a constant bark factor of 15.6 for second-growth redwood in Humboldt and Del Norte Counties, meaning that $15.6 \%$ of a tree's DBH comprised bark (both sides). Dividing this factor by two $(7.8 \%)$ makes it comparable to our data and models for one-sided average radial BT. Compared against our BT predictions for dominant and codominant trees in Humboldt County, the constant bark factor gives a $52 \%$ underprediction of BT for a small redwood $(15 \mathrm{~cm} \mathrm{DBH})$, a $2 \%$ overprediction for a $60 \mathrm{~cm}$ $\mathrm{DBH}$ redwood, and a $24 \%$ overprediction for a $135 \mathrm{~cm}$ DBH redwood tree. Therefore, we recommend replacing bark factors with the best available BT equations in forest science, modeling and management applications. We also recommend the adoption of our drilling method for BT measurement on larger trees due to the potential for error associated with bark gauge measurements [40].

Redwood stems within a sprout clump had a similar BT, and the BT varied widely among the clumps in the same stands. The strong genetic variance component for redwood BT suggests that BT should be assessed in tree improvement field trials along with other important traits such as tree size, form, health, epicormic branching and wood properties [41,42]. Redwood planting stock with thinner bark tendencies could be deployed in areas where wildfire risk is low (e.g., closer to the Pacific coast) with the objective of sequestering and storing more carbon into long lived wood products and producing less bark residues [43]. Alternatively, redwood planting stock with high BT could be deployed to more xeric and fire-prone inland areas [44], and for use in redwood range expansion 
projects where redwood is being planted outside its natural range in more stressful environments and may benefit from added protection from the elements [45,46].

\section{Conclusions}

In summary, redwood BT varied along gradients, at the tree level, in accordance with stand structure, as well as regionally. Factors other than DBH explained important amounts of variance and should be considered when modeling the BT instead of relying on simple bark factors that overpredict BT for larger, older trees such as those grown on longer rotations or to later ages under multiaged silviculture.

Author Contributions: Conceptualization and methodology, J.-P.B., K.L.O., N.E.K.; formal analysis, J.-P.B., N.E.K.; resources, K.L.O.; writing-original draft preparation and writing-review and editing, J.-P.B., K.L.O., N.E.K.; funding acquisition, J.-P.B., K.L.O. All authors have read and agreed to the published version of the manuscript.

Funding: This research was funded in part by the McIntire-Stennis Cooperative Forestry Research Program, project number ME042043. The APC was funded by credits received from the publisher for peer review and editorial service.

Acknowledgments: Field assistance was provided by Chris Ardis, Joseph King, Sophak Peou, Kirk Perttu, Merlin Sabo, and Cody Wright. We are grateful for logistic support provided by Jackson Demonstration State Forest, and research access permits from multiple public and private landowners.

Conflicts of Interest: The authors declare no conflict of interest.

\section{References}

1. Agee, J.K. Fire Ecology of Pacific Northwest Forests; Island Press: Washington, DC, USA, 1996.

2. Slack, A.W.; Kane, J.M.; Knapp, E.E.; Sherriff, R.L. Contrasting impacts of climate and competition on large sugar pine growth and defense in a fire-excluded forest of the Central Sierra Nevada. Forests 2017, 8, 244. [CrossRef]

3. Avery, T.E.; Burkhart, H. Forest Measurements; McGraw-Hill Education: New York, NY, USA, 2002.

4. Marshall, H.D.; Murphy, G.E.; Lachenbruch, B. Effects of bark thickness estimates on optimal log merchandising. For. Prod. J. 2006, 56, 87-92.

5. Li, R.; Weiskittel, A.R. Estimating and predicting bark thickness for seven conifer species in the Acadian Region of North America using a mixed-effects modeling approach: Comparison of model forms and subsampling strategies. Eur. J. For. Res. 2011, 130, 219-233. [CrossRef]

6. Ashton, M.S.; Kelty, M.J. The Practice of Silviculture: Applied Forest Ecology, 10th ed.; John Wiley and Sons: New York, NY, USA, 2018.

7. Laasasenaho, J.; Melkas, T.; Aldén, S. Modelling bark thickness of Picea abies with taper curves. For. Ecol. Manag. 2005, 206, 35-47. [CrossRef]

8. Maguire, D.A.; Hann, D.W. Bark thickness and bark volume in Southwestern Oregon Douglas-fir. West. J. Appl. For. 1990, 5, 5-8. [CrossRef]

9. Edmonds, R.L.; Agee, J.K.; Gara, R.I. Forest Health and Protection; Waveland Press, Inc.: Long Grove, IL, USA, 2011.

10. Biggs, A.R.; Merrill, W.; Davis, D.D. Discussion: Response of bark tissue to injury and inflection. Can. J. For. Res. 1984, 14, 351-356. [CrossRef]

11. Jackson, J.F.; Adams, D.C.; Jackson, U.B. Allometry of constitutive defense: A model and a comparative test with tree bark and fire regime. Am. Nat. 1999, 153, 614-632. [CrossRef] [PubMed]

12. Zeibig-Kichas, N.E.; Ardis, C.W.; Berrill, J.-P.; King, J.P. Bark thickness equations for mixed-conifer forest type in Klamath and Sierra Nevada Mountains of California. Int. J. For. Res. 2016, 1864039, 1-10. [CrossRef]

13. Dolph, K.L. Nonlinear Equations for Predicting Diameter inside Bark at Breast Height for Young-Growth Red Fir in California and Southern Oregon; Res. Note. PSW-RN-409; USDA Forest Service: Berkeley, CA, USA, 1989.

14. Oliver, C.D.; Larson, B.C. Forest Stand Dynamics, Update Edition; John Wiley and Sons: New York, NY, USA, 1996. 
15. Olson, D.F., Jr.; Roy, D.F.; Walters, G.A. Sequoia sempervirens (D. Don) Endl. Redwood (Agriculture Handbook 654). In Silvics of North America; Conifers; USDA Forest Service: Washington, DC, USA, 1990; Volume 1, pp. 541-551.

16. Berrill, J.-P.; O'Hara, K.L. How do biophysical factors contribute to height and basal area development in a mixed multiaged coast redwood stand? Forestry 2016, 89, 170-181. [CrossRef]

17. O'Hara, K.L.; Stancioiu, P.T.; Spencer, M.A. Understory stump sprout development under variable canopy density and leaf area in coast redwood. For. Ecol. Manag. 2007, 244, 76-85. [CrossRef]

18. Berrill, J.-P.; O'Hara, K.L. Estimating site productivity in irregular stand structures by indexing basal area or volume increment of the dominant species. Can. J. For. Res. 2014, 44, 92-100. [CrossRef]

19. Berrill, J.-P.; O'Hara, K.L. Patterns of leaf area and growth efficiency in young even-aged and multiaged coast redwood stands. Can. J. For. Res. 2007, 37, 617-626. [CrossRef]

20. Husch, B.; Beers, T.W.; Kershaw, J.A., Jr. Forest Mensuration, 4th ed.; John Wiley \& Sons, Inc.: New York, NY, USA, 2002.

21. Biging, G.S. Taper equations for second-growth mixed conifers of Northern California. For. Sci. 1984, 30, 1103-1117. [CrossRef]

22. Amidon, E.L. A general taper functional form to predict bole volume for five mixed-conifer species in California. For. Sci. 1984, 30, 166-171. [CrossRef]

23. Ryan, K.C.; Reinhardt, E.D. Predicting postfire mortality of seven western conifers. Can. J. For. Res. 1988, 18, 1291-1297. [CrossRef]

24. Hengst, G.E.; Dawson, J.O. Bark properties and fire resistance of selected tree species from the central hardwood region of North America. Can. J. For. Res. 1994, 24, 688-696. [CrossRef]

25. Pallardy, S.G. Physiology of Woody Plants; Elsevier: Boston, MA, USA, 2008.

26. Berrill, J.-P.; Jeffress, J.L.; Engle, J.M. Coast redwood live crown and sapwood dynamics. In Proceedings of the Coast Redwood Forests in a Changing California: A Symposium for Scientists and Managers; USDA Forest Service General Technical Report PSW-GTR-238; USDA Forest Service: Albany, CA, USA, 2012.

27. Mesavage, C. Measuring bark thickness. J. For. 1969, 67, 753-754.

28. Reineke, L.H. Perfecting a stand-density index for even-aged forests. J. Agric. Res. 1933, 46, 627-638.

29. Spurr, S.H. A measure of point density. For. Sci. 1962, 8, 85-96.

30. Burnham, K.P.; Anderson, D.R. Model Selection and Multimodel Inference: A Practical Information-Theoretic Approach; Springer: New York, NY, USA, 2002.

31. SAS Institute Inc. Base $S A S^{\circledR} 9.4$ Procedures Guide: Statistical Procedures, 6th ed.; SAS Institute Inc.: Cary, NC, USA, 2016.

32. Malone, T.; Liang, J. A bark thickness model for white spruce in Alaska northern forests. Int. J. For. Res. 2009, 876965, 1-5. [CrossRef]

33. Kirk, C.; Berrill, J.-P. Second-log branch size comparison between even-aged and multiaged Douglas-fir stands in coastal northern California. Math. Comp. For. Nat. Res. Sci. 2020, 12, 50-61.

34. Temesgen, H.; LeMay, V.; Mitchell, S.J. Tree crown ratio models for multi-species and multi-layered stands of southeastern British Columbia. For. Chron. 2005, 81, 133-141. [CrossRef]

35. Sprugel, D.G. When branch autonomy fails: Milton's Law of resource availability and allocation. Tree Phys. 2002, 22, 1119-1124. [CrossRef] [PubMed]

36. Pemberton, J.E., Jr. The relation of bark to diameter and volume in redwood. J. For. 1924, 22, 44-48. [CrossRef]

37. Stephens, S.L.; Libby, W.J. Anthropogenic fire and bark thickness in coastal and island pine populations in Alta and Baja California. J. Biogeogr. 2006, 33, 648-652. [CrossRef]

38. Bawcome, R.; Hubbell, R.J.; Burns, D. Seasonal Diameter Growth in Trees on Jackson State Forest; State Forest Note \#6. California. Division of Forestry: Sacramento, CA, USA, 1961.

39. Meyer, A. Bark volume determination in trees. J. For. 1946, 44, 1067-1070.

40. Stängle, S.M.; Weiskittel, A.R.; Dormann, C.F.; Brüchert, F. Measurement and prediction of bark thickness in Picea abies: Assessment of accuracy, precision, and sample size requirements. Can. J. For. Res. 2016, 46, 39-47. [CrossRef]

41. O'Hara, K.L.; Berrill, J.-P. Epicormic sprout development in pruned coast redwood: Pruning severity, genotype, and sprouting characteristics. Ann. For. Sci. 2009, 66, 409. [CrossRef] 
42. Meason, D.F.; Kennedy, S.G.; Dungey, H.S. Two New Zealand-based common garden experiments of the range-wide 'Kuser' clonal collection of Sequoia sempervirens reveal patterns of provenance variation in growth and wood properties. New For. 2016, 47, 635-651. [CrossRef]

43. Berrill, J.-P.; Han, H.-S. Carbon, harvest yields, and residues from restoration in a mixed forest on California's Coast Range. For. Sci. 2017, 63, 128-136. [CrossRef]

44. Pausas, J.G. Bark thickness and fire regime. Funct. Ecol. 2015, 29, 315-327. [CrossRef]

45. Dagley, C.M.; Berrill, J.-P.; Johnson, F.J.; Kerhoulas, L.P. Adaptation to Climate Change? Moving Coast Redwood Seedlings Northward and Inland. In Proceedings of the Coast Redwood Science Symposium-2016: Past Successes and Future Direction; USDA Forest Service Gen. Tech. Rep. PSW-GTR-258; U.S. Department of Agriculture, Forest Service, Pacific Southwest Research Station: Albany, CA, USA, 2017.

46. Kerhoulas, L.P.; Polda, W.; Kerhoulas, N.; Berrill, J.-P. Physiology and growth of Douglas-fir and redwood seedlings planted after partial harvesting. Front. For. Glob. Chang. 2020, 23, 49. [CrossRef]

(C) 2020 by the authors. Licensee MDPI, Basel, Switzerland. This article is an open access article distributed under the terms and conditions of the Creative Commons Attribution (CC BY) license (http://creativecommons.org/licenses/by/4.0/). 